\title{
FAMILY BUSINESSES AND THE CREATION OF ENTREPRENEURSHIP THROUGH THEIR INTERNAL RESOURCES
}

Recebido em 27.06.2014. Aprovado em 02.07.2014

Avaliado pelo sistema double blind review

DOI: http://dx.doi.org/10.12712/rpca.v8i2.464

\section{Gustavo José Nóbrega}

rjatoba@ig.com.br

Universidade de Brasília - Brasília - DF

\section{Valmir Emill Hoffmann}

ehoffmann@unb.br

Universidade de Brasília - Brasília - DF

\begin{abstract}
The purpose of this study is to analyse how family businesses can create a unique context for entrepreneurship through their internal resources, mentioned by Habbershon and Williams (1999) as familiness. Some researchers have used the resource-based view as a theoretical framework in order to investigate entrepreneurial capabilities in family firms which are one of the requirements to create wealth across generation and so we did. Moreover, family business must have the requirements that encourage them to be constantly involved in entrepreneurial activities. A single case study was conducted and semi-structured interviews with family and non-family members of the family firm A were made. We can conclude, despite the fact that this family firm has positive resources that foster entrepreneurship, it could not be classified as Enterprising Family since the culture of this organization does not meet the requirements described by Habbershon (2006) for an entrepreneurial family firm.
\end{abstract}

Key-words: Family Businesses. Entrepreneurship. Familiness. Resource-Based View.

\section{Resumo}

O objetivo deste estudo é analisar como as empresas familiares podem criar um contexto único para o empreendedorismo por meio de seus recursos internos, denominados por Habbershon e Williams (1999), como familiness. Alguns pesquisadores têm utilizado a visão baseada em recursos como referencial teórico, a fim de investigar as capacidades empreendedoras nas empresas familiares que são um dos requisitos para a criação de riqueza ao longo de gerações e foi o que fizemos. Além disso, a empresa familiar deve ter os requisitos que os encorajem a se envolverem constantemente em atividades empreendedoras. Um estudo de caso singular foi realizado e entrevistas semi estruturadas tanto com membros da família quanto membros não familiares foram realizadas na empresa familiar A. Podemos concluir, apesar do fato de que esta empresa familiar ter recursos positivos que promovam o empreendedorismo, essa organização não pode ser classificada como Família Empresária uma vez que a cultura desta organização não atende aos requisitos descritos por Habbershon (2006) que uma empresa familiar empreendedora deve possuir.

Palavras-chave: Empresa Familiar. Empreendedorismo. Familiness e Visão Baseada em Recursos. 


\section{FAMILY BUSINESSES AND THE CREATION OF ENTREPRENEURSHIP THROUGH THEIR INTERNAL RESOURCES}

\section{Introduction}

Family businesses are an important source of economic development and growth since they represent $70 \%$ of all the firms formally registered around the world (BERTIN, 2007). According to Leone (2005), family businesses, in Brazil, is responsible for almost $50 \%$ of gross domestic product and $60 \%$ of jobs. One of the greatest challenges to be overcome by policies of economic development is the need of family business to be more flexible and adaptive to environmental demands and to develop entrepreneurial characteristics (FREITAS; Krai, 2010).

The concept of family business which was adopted in this study was proposed by Westhead and Cowling (1998) who said that that family firms are one family group who controls the company through a clear majority of the ordinary voting shares, this family is represented in the management team, and the leading representatives of the family perceive the business to be a family firm. The positive aspect of this definition is that it places emphasizes on not just technical definitions of family business such as controlling voting shares or the number of family members involved in the business, but also on psychological issues such as how family members perceive their business, which is important due to the fact that it can have an impact on the level of commitment of each family member towards the business.

Despite the great impact that family businesses have at the economy of many countries, they are normally described in the literature as being introverted, inflexible and resistant to change (MELIN; NORDQVIST, 2002). Over time, some become conservative and unwilling to take risks associated with entrepreneurship (AUTIO; MUSTAKALLIO, 2003). Lerner (1996) mentions that family businesses have its own features which represent special challenges and the solution of them are, normally, not so easy.

Family firms have been characterized with traditions that are against entrepreneurship (HABBERSHON, 2006) since the next generations run the business in the same way of the previous generations due to strong traditions and values (HALL, 2002). This fact, in accordance with Aronoff and Ward (1997), is called inertia, capable to cause resistance to change. Moreover, another feature of family business that can jeopardize the entrepreneurial spirit is the decision making process which normally depends just on the family entrepreneur (HABBERSHON, 2006), with founders that do not usually delegate power (KETS DE VRIES, 1996). Besides, there are many founders of family firms who are comfortable with the current situation and are not willing to increase the profitability of the business since this would imply an increase of effort, risk or investment (ZAHRA; HAYTON; SALVATO, 2004).

Due to the important role that family firms play in the economics of many countries and the fact that entrepreneurship is important for value creation, it is essential that family firms pursue entrepreneurial activities (ZAHRA et al, 2004). In order to firms to be more entrepreneurial, it is necessary to focusing on developing their internal core competencies and matching them with market opportunities (HABBERSHON; PISTRUI; MCGRANN, 2001). For family businesses, this means that they have to focus on developing distinct familiness which means "...as the unique bundle of resources a particular family firm has because of the systematic interaction between the family, its individual members, and the business" (HABBERSHON; WILLIAMS, 1999, p. 11).

In addition, the familiness can be classified in two categories "...distinctive familiness to refer to the component of a firm's familiness that provides them with a potential advantage and allows them to deliver offerings that other firms cannot match and customers preferences" and 
"constrictive familiness" when these resources do not provide an advantage for the business (HABBERSHON; WILLIAMS, 1999, p. 13).

The general concern of this study is in line with the trans-generational concept that according to Habbershon (2006, p.80) “...refers to how families adopt the entrepreneurial mindset and capabilities to generate new economic activities within each generation, which in turn creates continuous streams of wealth across many generations". The purpose of this study is to investigate the internal resources, familiness, of the family firm and to describe how their familiness can encourage the entrepreneurial capabilities which can create wealth across generations.

\section{Frame of reference}

The field of Family Business is still in its infancy in Brazil. Martins, Maccari, Campanario and Almeida (2008) mention that from the period of 1996 to 2005, from the 3.825 articles published at the Annual Meeting of Post-Graduate Programs of Business Administration (ENANPAD), just 14 analyzed the management in the field of family business. Borges, Brito and Lescura (2012) mention that succession is the most prevalent topic $(22,9 \%)$ in Brazilian journals, among issues normally discussed in the family business literature, followed by strategy $(8,0 \%)$, governance $(8,0 \%)$ and organizational culture $(6,0 \%)$.

\section{Resource-Based View for Understanding Entrepreneurial Capabilities}

The Resource-Based View (RBV) has been used by many scholars (HABBERSHON; WILLIAMS, 1999; SIMON; HITT, 2003; POZA, 2007) for understanding the unique characteristics and the competitive advantage of family firms. Wernerfelt (1984) argues that the terms resources and capabilities are defined in several different ways and there is no consensus on the proper terminology. The concept of capabilities adopted in this study was suggested by Makadok (2001, p. 389) who defines as “... special type of resource - specifically, an organizationally embedded nontransferable firm specific resource whose purpose is to improve the productivity of other resources" (as cited in HABBERSHON, WILLIAMS; MACMILLAN, 2003, p. 459).

Habbershon and Williams (1999, p. 11) after conducting a review in the literature (BARNEY, 1991; GRANT, 1991) classify the resources in family firms into four categories which are physical capital resources (plant, raw materials, cash, access to capital, intellectual property), human capital resources (skills, knowledge, training, relationships), organizational capital resources (competencies, control, policies, culture, information, technology), and process capital resources (knowledge, skills, disposition and commitment to communication, leadership and the team).

The heterogeneous resources and capabilities can be a source for organizations to achieve sustainable competitive advantage when they are valuable (help the organization to implement its strategy effectively and efficiently), rare (resources are not shared by a large number of competitors), hard to copy (competitors cannot merely duplicate them) and no substitutable with other resources (BARNEY, 1991).

It is seems to us that family firms are best analyzed through the specific complex, rich and intangible resources that are unique to the enterprise-household complex. Sharing the same idea, entrepreneurship in family firms is better understood using the familiness approach developed by Habbershon and William (1999) rooted in the resource-based view of the firm. 


\section{FAMILY BUSINESSES AND THE CREATION OF ENTREPRENEURSHIP THROUGH THEIR INTERNAL RESOURCES}

The same author state that because of family firms have been described as unusually complex, dynamic and rich in intangible resources, the RBV gives researchers in the field of family business an appropriate means to analyze them.

\section{Entrepreneurial Capabilities in Family Firms}

The entrepreneurial capabilities described in this study is originated from the study of Habbershon (2006) who classify them as opportunity seeking, insight bursting, decision making, bootstrapping, venture financing, team building, habitual entrepreneur and entrepreneurship reproducing.

Habbershon (2006) has associated opportunity seeking with networks and tacit knowledge as resources that can help family firms to identify new opportunities. Networks in family firms are characterized by strong kinship ties and they are based on personal connections that offer the family to see opportunities ahead of competition. The second resource, tacit knowledge, is normally derived from the experience of an individual and they are personal, difficult to convey and it is also not easily to express this knowledge in the formality of language (MORRIS; KURATKO, 2002).

Insight bursting is related to entrepreneurial alertness which is the ability to notice things without engaging in deliberated search (BARRINGER; IRLEAND, 2006). The resources that can foster this capability are organizational governance since the family governance structure is "[...] reflective of more intuitive process and they are used in accommodating infused insights and new directions", decision making as they are "...also reflective of the heuristic process associated with bursting" and tacit knowledge which "...are particularly deep in multigenerational teams since children grow up in the business ...and can produce bursts of insights around internal process opportunities" (HABBERSHON, 2006, p. 88).

Decision making is referred by Habbershon (2006) as one of the most important entrepreneurial capabilities that can bring competitive advantage to family business and it is influenced by entrepreneur's cognition which is characterized by the use of heuristic and organizational system. He continues to explain that tacit knowledge, operational process capabilities, intuitive insight and actions are the basis for simplified strategic thinking (heuristic) in family business which helps the entrepreneurial process and bring competitive advantage.

According to Habbershon (2006, p.89), bootstrapping is defined as “...discovering, mobilizing, or leveraging resources and capabilities currently controlled by the entrepreneur" as a key success factor in the entrepreneurial process. Moreover, the same author explains that there are different ways for entrepreneurs to find and to mobilize this resource such as "...talk to people to see what they can add; explore networks and opportunities; leverage friends and family; scrape together what they can find; and put a lot of personal sweat equity into the business". The network is the resource which is associated with bootstrapping.

One of the most enduring challenges in the entrepreneurial process is the mobilization of financial resources (BARRINGER; IRELAND, 2006). Habbershon (2006, p. 91) points out that "[...] the reverse side of a financing advantage is how families leverage their social network to create an advantage in obtaining funding" and other characteristics of family such as the "control over the allocation of resources, owners/manager decision making, and intuitive-based 
tacit knowledge" can bring important advantages to family firms in their financial decision making process.

Johannisson (2004) concluded in his research that human capital is the most important resource for family business followed by social capital and financial capital. In a family firm, the management team has a particular characteristic due to the presence of family members. Habbershon (2006) states that this context creates a natural advantage for family firm since they are a collection of individual who live and work together. It is important to remember that he emphasizes that this does not mean that families are always good team. However, Habbershon (2006, p. 91) states that "families also have the potential to become transgenerational teams and to continue their entrepreneurial family vision and legacy across many generations".

Entrepreneurs can also be different regarding their ownership experience. In line with this criteria, Ucbasara, Westhead and Wright (2006, p.4) classify entrepreneurs into novice entrepreneurs to refer "...to individuals with no prior minority or majority business ownership experience" and habitual entrepreneurs as "... individuals who hold or have held a minority or majority ownership stake in two or more business". In addition, Habbershon (2006) mentions that families are often habitual entrepreneurs and the resources associated with this capability are mentoring relationship and business portfolio.

The last capability is entrepreneurship reproducing which is based on the idea that many of the new products, services, ideas and structures that entrepreneurs bring to market are very similar to the ones that already exist and should not be classified as innovations but as reproductions (ALDRICH; MARTINEZ, 2001). In line with such thinking, Habbershon (2006) states that families are naturally great reproducers and extenders of markets and family networks and portfolio businesses are considered resources that can leverage the entrepreneuring reproducing.

\section{Enterprising Families}

Our analyze was based on the study of Habbershon (2006) in order to categorize the family firm A as enterprising family which should have certain types of mindset and methods that allow it to generate wealth across generations. The same author mentions that the analysis of entrepreneurial strategies and behavior in a family business must be preceded by an investigation of organizational culture, which he refers the "entrepreneurial mindset", that allows organizations to develop an entrepreneurial behavior. Moreover, the enterprising families must develop certain types of entrepreneurial strategies, described as methods, which allow organizations to take advantages of opportunities that are created by changes in dynamic markets. 


\section{FAMILY BUSINESSES AND THE CREATION OF ENTREPRENEURSHIP THROUGH THEIR INTERNAL RESOURCES}

The entrepreneurial mindset and methods proposed by Habbershon (2006) can be visualized in the Figure 1:

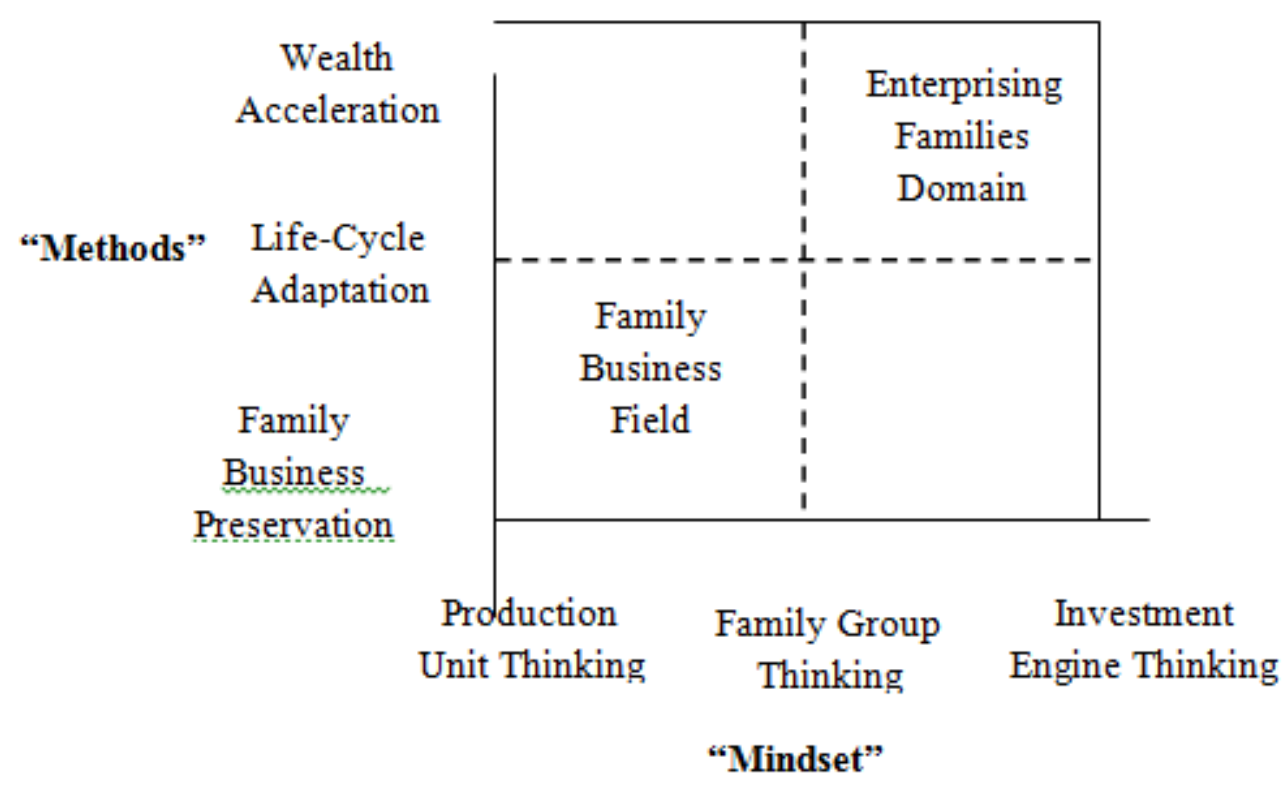

Figure 1: Enterprising Families Domain

Habbershon (2006) mentions that in a stable and low speed environment it would not be a problem for a family firm be classified as family business field. However, in a dynamic highvelocity environment, the organization should be more market responsiveness. Consequently, firms operate under this environment must develop a wealth acceleration strategy and an investment engine thinking mindset. The same author states that in order for an organization be classified as enterprising families domain, the family business must present the following characteristics:

a) Leadership Dimension: characterized by a participative style which people are empowered and decision making does not depend on a single person;

b) Vision Dimension: which implies that organizations must have an explicit vision to create a multigenerational legacy of wealth creation. In addition, the vision must proactively focus on growth;

c) Performance Dimension: which means that firms systematically look for opportunities that can create above average returns in the market;

d) Strategy Dimension: refers to strategic process that emphasizes the development of internal core competencies or familiness which can be a source of competitive advantage;

e) Form Dimension which implies the organization must develop form, which means the company needs to constantly change not just the organizational structure but also the strategy, to allow the family business to continually search for new opportunities;

f) Process Dimension which refers that organization must create and maintain a process that focus on generating and integrating new knowledge and information in order to acquire new capabilities.

\section{Method}

The qualitative studies emphasize the socially constructed nature of reality, the strong 
relationships between the researcher and the investigation, and the situational constraints that shape inquiry (DENZIN; LINCOLN, 2003). These characteristics of qualitative analysis can also be realized in this study since the aim is to investigate the internal resources, familiness, of the family firm $A$ and to describe how their familiness can encourage the entrepreneurial capabilities which can create wealth across generations.

In a qualitative research, there are different ways of conducting an investigation such as experiments, surveys and case studies (YIN, 1994). The case study was chosen as the research strategy of this investigation due to the following reasons: first of all, the unit of analysis of this study is a single organization where entrepreneurship can be considered as a kind of organizational behavior. Moreover, the familiness, which is also one of the variables under investigation in this study, is difficult to quantify.

According to Patton (2002), the three main sources of data collection in a qualitative study are interviews, observations and written documents. Yin (1994) mentions that interviews are the main source of getting information in a case study. This study was based on information collected through interviews with different members of this family firm. Semi-structure interview was chosen as the method since it gives the researcher the freedom to ask more question, during the interview, as he or she realizes that it is important to add, in order to understand the phenomenon (WELMAN; KRUGER; MITCHELL, 2005).

The analysis categories of this study were based on identifying and investigating the familiness of this family firm. The familinesses were classified into four sub-categories: organizational capital resources, physical capital resources, human capital resources and process capital resources. Thereafter, those subcategories were related to the entrepreneurial capabilities described by Habbershon (2006). These analyses were done in order to identify if the family firm A can be classified as an enterprising family suggested by Habbershon (2006) and in case of a negative verification, how the company should exploit their resources in order to be categorized as an enterprising family.

\section{Results}

There are two businesses owned by the entrepreneur of family firm A which constitute a business portfolio. The entrepreneur of the family firm $\mathrm{A}$ is a minority shareholder of a transportation company and owns some of the buses of this company. The second business, the one which is going to be investigated in this study, is a workshop, founded in 2003, and the two main services offered are electrical and mechanical systems. These services are considered as the core competencies of the business. Additional services that could be necessary are outsourced by the workshop. The main costumer of this organization is the buses from the transportation company that the entrepreneur is a minority shareholder. Additionally, this organization has had other clients, occasionally. The workshop started with five employees, where two of them are family members. Currently, this family firm presents the same size in terms of number of services offered and employees as it started in 2003.

Regarding the governance structure, the company does not have any governance body such as board of director, family council, shareholders' assembly and shareholder agreement because the entrepreneur has $100 \%$ of shares. Moreover there is not any formal organizational structure as different departments and units. 


\section{FAMILY BUSINESSES AND THE CREATION OF ENTREPRENEURSHIP THROUGH THEIR INTERNAL RESOURCES}

\section{Interpretation of the Familiness \\ Physical Capital Resources}

The financial capital resource is a positive familiness for this business since the family firm provides funds to family members in order for them to get involved in the entrepreneurial process. As a result, the family is considered as a significant source to finance family members' business creation and this is at the utmost importance since one of the most enduring challenges in the entrepreneurial process is the mobilization of financial resources (SHARMA, 2004).

Another way to get access to financial capital which was identified in the family firm A is through its network since the good relationship that the company develops with its suppliers provides credit agreement. The other resource is the business portfolio since the other business which the entrepreneur was involved had a significant influence in helping the start-up of this business in the way that it provided funds. With such considerations, the physical capital resource is a distinctive familiness for this family firm since it creates value to the business and help in the entrepreneurial process.

\section{Human Capital Resources}

This type of resource was related to network, tacit knowledge and mentoring relationships in the family firm A. The network of this organization is comprised by relationships with customer, suppliers and other companies in the same industry. The company has developed a good relationship with other workshops. This network has provided advantages to the organization in terms of sharing information and technical knowledge. As a result, this network helps the organization in providing better service.

Another distinct characteristic of the network of this organization is the fact that the first and the second generation share the same network. Moreover, the manager of this firm, which is a member of the second generation, has helped the business to develop their network. In addition, the relationships that the company holds with different stakeholders are characterized as being outspoken and based on friendship ties. It can be concluded that the network in this organization is a distinctive familiness, despite the fact that it could be better exploited.

\section{Organizational Capital Resources}

The culture of this organization creates value to the business and, consequently, is a distinctive familiness. This is supported by the fact that the communication process allows the business to communicate and to exchange information more efficiently. The culture of family firm A supports the entrepreneurial process since the failure culture which is one of the characteristics of this family firm encourage family members to be involved in entrepreneurial activities in this business. The fact that this organization promotes learning creates a positive environment in which employees can make the best of their work (SHAKER, JAMES \& CARLO, 2004).

The second resource that is related to organizational capital is decision making process. As it was already described, there is a decentralization of control since power and decisions are not concentrated on just one person, in this case, the entrepreneur. As a result, the decision making process creates values to the business, since, according to Habbershon (2006) decentralization and open decision making is positively related to entrepreneurship. Another way that the decision making process brings value to the organization is the fact that this process is quickly and in this way the company can be more market responsiveness. The tacit knowledge is one of 
the main elements in this business that allows the organization to make quick decisions (BURNS, 2005).

\section{Process Capital Resource}

The process capital resource in this organization is related to team building. In this case, the family members have taken advantage of the natural tendency to work as team. This positive relationship brings about the potential to become transgerenational team and to transfer values across many generations (HABBERSHON, 2006). To sum up, team building is a distinctive familiness that brings advantages to the business and helps the organization to be more entrepreneurial.

\section{Familiness and Entrepreneurial Capabilities}

In order to understand how the familiness can foster entrepreneurship, the entrepreneurial capabilities described by Habbershon et al (2003) and the resources that can enhance these capabilities were investigated. This analyze is described in the Table 1.

\begin{tabular}{l|l}
\hline Entrepreneurial Capabilities & Resources \\
\hline Opportunity Seeking & $\begin{array}{l}\text { Access to Financial Capital, Business } \\
\text { Portfolio, Network, Tacit Knowledge, } \\
\text { Mentoring Relationship and Decision } \\
\text { Making }\end{array}$ \\
\hline Insight Bursting & $\begin{array}{l}\text { Tacit Knowledge } \\
\text { Tacit Knowledge, Culture and Decision } \\
\text { Making }\end{array}$ \\
\hline Decision Making & \begin{tabular}{l} 
Business Portfolio and Network \\
\hline Bootstrapping
\end{tabular} \\
\hline Venture Financing & $\begin{array}{l}\text { Access to financial Capital, Network and } \\
\text { Culture }\end{array}$ \\
\hline Team Building & $\begin{array}{l}\text { Mentoring } \\
\text { teambuilding }\end{array}$ \\
\hline Habitual Entrepreneuring & $\begin{array}{l}\text { Mentoring Relationship and Business } \\
\text { Portfolio }\end{array}$ \\
\hline
\end{tabular}

Table 1 Resources and Capabilities of the Family Firm

It is possible to realize through this graphic that some resources foster more than one capability. In addition some capabilities can also be considered as a resource such as team building and decision making process.

\section{Assessment of Familiness}

The main criteria that was used to classify the resource as distinctive or constraint resides on the fact that if they create an advantage or not the business. 


\section{FAMILY BUSINESSES AND THE CREATION OF ENTREPRENEURSHIP THROUGH THEIR INTERNAL RESOURCES}

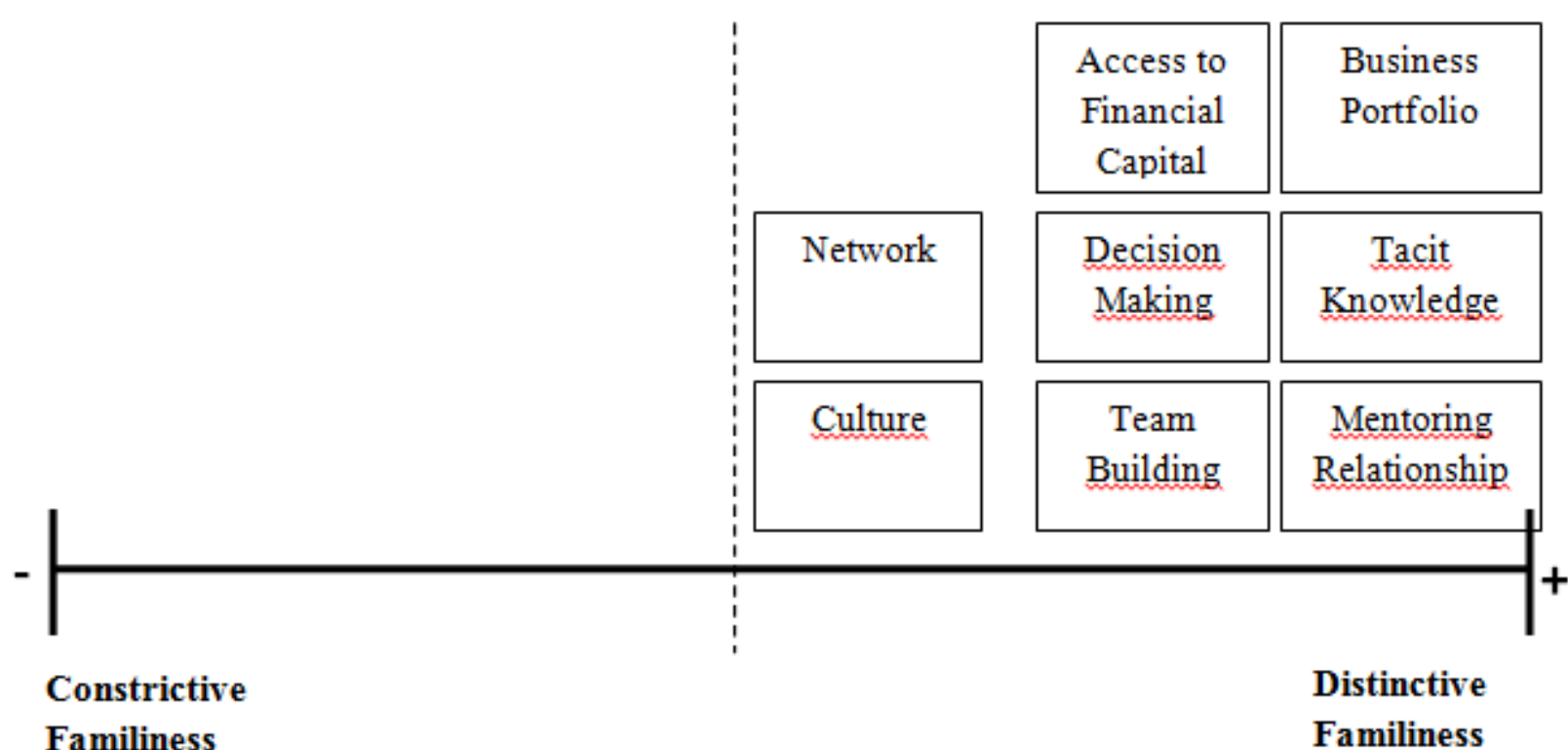

Figure 2: Advantage Constraint Continuum.

From the Figure 2, we can realize that network could add more value to the business since the family firm does not have relationships with potential clients and in this way the organization limits its spectrum of opportunities. The fact that the values of this organization are not explicit and communicated through the business inhibits the entrepreneurial process as Hall et al (2001) concluded in their study. As a result, the culture of this organization could bring more advantages to the business. On the one hand, all the other resources significantly contribute to business by adding different capabilities. Moreover, business portfolio, tacit knowledge, mentoring relationship are the firm's resources that most distinct create familiness. On the other hand, culture and network do not bring too many values to this family business and as a result they are not considered distinctive familiness. This can be visualized in the graphic due to the fact that these resources are more located on the left side. A slightly differentiation from the position of some the resources can be noticed. This difference was based on our perception regarding how these resources can create value to the business.

\section{Enterprising Families Domain}

From the empirical findings that were gathered in this study, this business concentrates its strategies on operational day-to-day activities due to the fact that this organization has not been involved in other activities since its foundation. As a result, from the strategic point of view, this family firm can be classified as Family Business Preservation.

Decisions in this organization do not depend on just one person. In addition, people are empowered and leadership style is not autocratic. These characteristics of the leadership style fit what Habbershon (2006) has recommended that an Enterprising Family Domain should present.

The vision of this organization is not explicit which means that it is not known by organizational members and does not fit the criteria of Enterprising Family since firms that do not have an explicit vision to create multigenerational legacy of wealth creation cannot be said to be an enterprising family (HALL et al, 2006).

Regarding performance, due to the fact that this family firm is not systematically involved in 
searching and exploiting new opportunities to reach above average return, it should not be classified as an Enterprising Family Domain.

This organization supports and encourages the development of learning. As a result, the process dimension is positive associated in this organization despite the fact that there is not a formal process in this family business to generate new knowledge in order to acquire new capabilities. With such considerations, according to the methods and the mindset suggested by Habbershon (2006), this family business is considered as a Family Business Field.

\section{Conclusions}

The resources and capabilities of the entrepreneur's workshop are distinctive familinesses that create values to the organization. The business portfolio, tacit knowledge and mentoring relationships are resources that bring clear advantages to this business and help the organization to be more entrepreneurial since they are related to the development of different capabilities such as opportunity seeking, insight bursting, team building and others. The deeper tacit knowledge in this organization can be explained due to the long experience of family members in the business, which brings important benefits to the organization such as knowhow, expertise and knowledge. The tacit knowledge is an important source for this organization to achieve competitive advantage due to the fact that it is a valuable resource and it is embedded in elements which are difficult to be copied by its competitors such as past experience and the history of entrepreneurs (BARNEY, 1991). In addition, the fact that the first generation is actively involved in transmitting knowledge and experience to the next generation was also verified in this study. Mentoring relationship was considered as a distinctive familiness since it helps the business in transmitting not just the formal knowledge but also the values, norms and beliefs which are important elements that the next generation should know in order to take over the business and to manage the organization efficiently and effectively. Moreover, business portfolio, which in this case is related to both business, the workshop and the entrepreneur's buses, provides resources such as labour, experience and financial resources, which help the organization to be involved in entrepreneurial activities.

Team building, access to financial capital and decision making are distinctive familiness in this family firm. Family Members is a positive asset for this organization since family members work well as team not just with each other, but also with non-family members which creates an environment that can foster entrepreneurship. The access to financial capital that in this organization can be obtained from family members as well as from the social network creates an important value for this family business since it can facilitates family members to finance their venture activities. Moreover, the decision-making process in this organization reflects a consultative style where people are empowered. These characteristics are related to entrepreneurship since employees are encouraged to look for new opportunities (Wilklund, 1998). In addition, the organization encourages employees to express their ideas and suggestions regarding the business and this aspect is a way to foster innovation.

The last two resources, network and culture, are the ones that this family business should try to better explore them in order to get more advantage from them. Regarding the network, despite the fact that this resource creates values to the business, it should be improved. This can be explained since important stakeholders that could bring advantages to the organization, such as potential clients, are ignored by the family firm. With reference to the culture, it is possible to realize, from the empirical findings and analysis, that with the goal to support a more entrepreneurial orientation, the culture must be open and explicit (HALL et al, 2001) which is 


\section{FAMILY BUSINESSES AND THE CREATION OF ENTREPRENEURSHIP THROUGH THEIR INTERNAL RESOURCES}

the case in this family firm, since the values, norms and beliefs are not clearly expressed.

In order for this organization be classified as enterprising family, we recommend to this family firm be involved in the following activities:

a) the development of an explicit vision that engages and motivates family and non-family members towards a common goal. This aspect is important since the vision is a key element of entrepreneurship and leadership. Moreover, it is paramount that the vision should be continually checked with the staff to ensure that the vision has a resonance with them;

b) the firm should be continually involved in looking for new opportunities which can be done by developing an entrepreneurial culture that clearly expresses and encourages through its values and beliefs an opportunistic behaviour;

c) the firm should systematically analyze, check and if it is necessary, develop its internal resources (familiness) in order for them to match its capabilities with the requirements from the external environment and to capture new opportunities.

This study has some limitation due to the fact that this is a single case study which limits the analyses to the characteristics of this organization, specially, its size and the industry which operates. Despite these limitations, we understand that the purpose of this study was fulfilled since it was possible not just to analyse the internal resources of this family firm that foster entrepreneurship, but also to make some recommendation regarding how this family firm should be more entrepreneurial based on the study of Habbershon (2006).

As suggestions for future research, we could recommend to apply the Habbershon model for investigating entrepreneurship in family business in firms with different sizes and stages of its life cycle operating in diverse industries. This analyse is important in order to identify some of the gaps in the model presented in this study and ways that it could be improved.

\section{References}

ALDRICH, H.E.; MARTINEZ, M.A. Many are called, but few are chosen: an evolutionary perspective for the study of entrepreneurship. Entrepreneurship, Theory, \& Practice Journal, 41-56, 2001.

ARONOFF, C.E.; WARD, J.L. Preparing your family business for strategic change. Marietta, GA: Family Enterprise Publishers. 1997

AUTIO, E.; MUSTAKALLIO, M. Family firm internationalization: A model of family firm generational succession and internationalization strategic postures. Paper presented at the Theories of the Family Enterprise Conference, University of Pennsylvania, Philadelphia. 2003.

BARNEY, J. B. Firm resources and sustained competitive advantage. Journal of Management, Stillwater, 17 (1), 99-120, 1991.

BARRINGER, B. R.; IRELAND, R. D. Entrepreneurship: successfully launching new ventures. Upper Saddle River, N.J.: Pearson Prentice Hall. 2006 
BERTIN, M. E. J. A qualidade da governança em empresas familiares. Governança corporativa: excelência e qualidade no topo. Rio de Janeiro: Qualitymark, 2007.

BORGES, A.F.; BRITO, M.J.; LESCURA, C. O campo de Pesquisas sobre Empresas Familiares no Brasil: análise da produção científica no período de 1997-2009. Revista Eletrônica de Gestão Organizacional. 10 (3), 595-622, 2012.

BURNS, P. Corporate Entrepreneurship: Building an Entrepreneurial Organization. Palgrave MacMillan, 2005.

DENZIN, N. K.; LINCOLN, Y. S. Handbook of Qualitative Research. Thousand Oaks, Ca.: Sage, 1994.

FREITAS, E.C.; KRAI, L.C. Gestão organizacional em empresas familiares no vale do rio dos Sinos. Revista de Gestão de Pessoas, 17 (4), 387-402, 2010.

GRANT, R.M. The Resource-Based Theory of Competitive Advantage: Implications for Strategy Formulation. California Management Review, 1991.

HABBERSHON, T.G. The Family as a Distinct Context for Entrepreneurship. Praeger Perspectives on Entrepreneurship, 2006.

HABBERSHON, T.G.; WILLIAMS, M. L.; MACMILLAN, I.C. A Unified Systems Perspective of Family Firm Performance. Journal of Business Venturing, 18, 451-465, 2003.

HABBERSHON, T.G.; PISTRUI, J.; MCGRANN, M. Enterprising Families: Mindset and Methods for Wealth Acceleration in a Dynamic Marketplace. Family Business Review, 14, 180-195, 2001.

HABBERSHON, T.G.; ; WILLIAMS, M.L. A Resource-Based Framework for Assessing the Strategic Advantage of Family Firms. Family Business Review, 12 (1), 1-26, 1999.

HALL, A.; MELIN, L; NORDQVIST, M. Understanding Strategizing in the Family Business Context. In: Poutziouris, P.; Smyrnios, K.; Klein, S. Handbook of Research on Family Business, Cheltenham: Edward Elgar, 2006.

HALL, A. Towards an understanding of strategy processes in small family businesses: a multirational perspective. In: Fletcher, D. (Ed.) Understanding the Small Family Business. London: Routledge Studies in Small Business, 2002.

JOHANNISSON, B. The Social Construction of the disabled and unfashionable family business. In: Nordic Conference on Small Business Research, Tromsö, Norway, 2004.

KETS de Vries, M. 'The Anatomy of the Entrepreneur'. Human Relations, 49, 853-884, 1996. LEONE, N.C.P.G. Sucessão na empresa familiar. São Paulo: Atlas, 2005.

MARTINS, A.; MACCARI, E. A.; CAMPANARIO, M. A.; ALMEIDA, M. I. R.. Empresa familiar e as dificuldades enfrentadas pelos membros da terceira geração. Revista de Ciências da Administração, 10, (22), 30-54, 2008.

MORRIS, M.H.; KURATKO, F.D. (2002) Corporate Entrepreneurship. Harcourt College Publishers, 2002.

PATTON, M. Qualitative Research \& Evaluation Methods. London: Sage, 2002. 


\section{FAMILY BUSINESSES AND THE CREATION OF ENTREPRENEURSHIP THROUGH THEIR INTERNAL RESOURCES}

POZA, E.J. Family Business. Thomson South-Western, 2007.

SHAKER, A.; JAMES, C.; CARLO, S. Entrepreneurship in Family vs. Non-Family Firms: A ResourceBased Analysis of the Effect of Organizational Culture. Entrepreneurship: theory and practice, 2004.

SHARMA, P. An overview of the field of family business studies: current status and directions for the future. Family Business Review, 17 (1), 1-36, 2004.

SIMON, D.G. ; HITT, M.A. Managing Resources: Linking Unique Resources, Management, and Wealth Creation in Family Firms. Entrepreneurship: theory and practice, 2003.

UCBASARAN, D.; WESTHEAD, P.; WRIGHT, M. Habitual Entrepreneurs. Oxford : Oxford University Press, 2006.

WELMAN, C.; KRUGER, F.; MITCHELL, B. Research Methodology. Capetown : Oxford University Press, 2005.

WESTHEAD, P.; COWLING, M.. Family firm research: The need for a methodological rethink. Entrepreneurship Theory \& Practice, 23, 31-56, 1998.

WERNERFELT, B. A resource-based view of the firm. Strategic Management Journal. 5, 171180, 1984.

WIKLUND, J. Small Firm Growth and Performance: Entrepreneurship and Beyond. Jönköping: Jönköping International Business School, 1998.

YIN, R. Case Study Research: Design and Methods. Thousand Oaks, CA.: Sage Publications, 1984.

ZAHRA, S.A.; HAYTON, J. C.; SALVATO, C. Entrepreneurship in family vs. non-family firms: A resource-based analysis of the effect of organizational culture. Entrepreneurship Theory and Practice, 28 (4), 363-381, 2004. 